\title{
CONTRIBUTION OF PHYSICAL PLANNING AND REGIONAL POLITICS TO THE REVITALIZATION AND NEW USE OF THE RALSKO AREA
}

J. Dařílková: Contribution of Physical Planning and Regional Politics to the Revitalization and New Use of the Ralsko Area. - Geografie - Sborník CGS, 103, 3, pp. 331 - 346 (1998). - The introduction of physical planning and regional policy is inevitable in order to successfully revitalize the Ralsko region. Physical planning is perceived as an open system that offers various methods which can help to solve the most pressing local problems. The article also discusses all relevant physical planning documents of the Ralsko region since 1994 including crucial concepts and problems.

\section{Introduction}

1.1 Development of the area in question since the end of the second world war

Until 1946 the people of the Ralsko area had mostly lived a civil life. At that time there already existed 20 mostly agricultural villages and a little town Kuřivody, which was the natural center of this area.

With a Czechoslovak law passed on 27. 4. 1949 No. 169/1949 Sb. it was decided to set up here by 1. 7. 1950 the military training zone Ralsko for army-training the troops of the Czechoslovak Army (ČSA).

In the years 1946 - 1950 the villages were desettled step-by-step and the whole area was transfered to the army, but there were no permanent troops there. This milatary zone partly caused the absolute destruction of about 20 villages and entirely changed the character of the villages which survived ( e.g. the reknowned recreation center Hradčany and others).

But after 1968 the Soviet army came to replace the Czechoslovakia army and would stay permanently. Uranium mining was started in the surroundings of Stráž pod Ralskem in the early 70s. The mining significantly limited civil use of the northern part of the area.

Both these facts partly caused the borders of the military zone to become even more closed and the whole area became significantly more isolated.

Following the 1991 departure of troops and the gradual ending of uranium mining the territory of the military zone was reopened and transfered to civil use from 31. 12. 1991. The independent municipality of Ralsko was declared on 1. 1. 1992, and in march 1992 local board of representatives started acting. At the same time changes came about in the administration demarcation and arrangement of the municipality.

The former military training area of Ralsko (with an area of aprox. 25,000 ha), a devastated landscape with just a fragment of the former settlement, 
was transfered to the civil sector for reuse. (Aside from army use, the devastation of the landscape was partly caused by the extensive chemical uranium mining in the northern part of the area too).

An urgent need to obtain physical planning documentation and necesssary data for the quick joining of the freed area to the urban structure of a larger area (esp. districts Ceská Lípa, Liberec and Mladá Boleslav) existed.

For a quality elaboration of those documentations it was necessary to evaluate a lot of information (evaluating the conditions of the area) through a more detailed understanding, evaluating positive and negative factors and expressing problems for a conception of the new area reuse.

\subsection{Physical planning problems of the Ralsko area}

The necessity of physical planning generally, and in the mentioned area especially, can be seen in two aspects:

1. Physical planning must be an open system, applicable in spectra of possible and unpredictable needs, whose pressure is expected and will probably increase in the near future.

2. Physical planning should professionally offer real, even if different, ways to solve important questions, whose validity is significantly determined by those values lifetime in the area in question.

The reciprocity of these two sometimes even antagonistic moments of physical planning offers leads to these demands of conception:

- to evaluate not only a summary of permanent but even temporary priorities represented in the area in question, name them, state their priorities, degree of resistance to time factors (durability)

- to find and compare methods of solution and to work out attractive (in both social and business senses ) and realistically orientated offers.

The permanent (or long-term) preferences of the solved area are generally seen in the geographical aspects (in location, in the large palette of natural deposits - sometimes even phenomena), in a continuous urban region, in the possibility of the area being dynamically used for some activities (international travel, sport and recreation, eventually a spa etc.) On the other hand the shortterm, in fact endangered by short-durability, aspects consist in the values of housing estate funds and local technical, and traffic infrastructure. It's necessary to see that the permanent and long-term preferences of the area have mostly not lost their quality with the lapse of time since leaving the former military area - probably they have even gained in quality. Devastation and pollution of the environment by the military and traffic machines ended, the increasing threat to water sources by uranium mining contamination ended too, ammunition in the area is being disposed of and the potential danger of a return to civil activities to renewing forest and agriculture area farmsteads, nature protection and the access of tourists to the long forbidden and unknown (or forgotten), in places very interesting localities.

On the other hand short-termed, mainly characterised by-short-durability, deposits of the area (uninhabited, unkept, becoming worn out, abandoned and insufficiently guarded objects and buildings) were exposed to changes of seasons, weather, but even people of low-society (thieves and vandals) and the combination of these effects, which every year speeds up the depreciation and destruction of the mentioned funds.

If some urban conceptions could in the early 90 s count on using most of the abandoned funds, in the mid-90s on using some funds after reconstructions, 


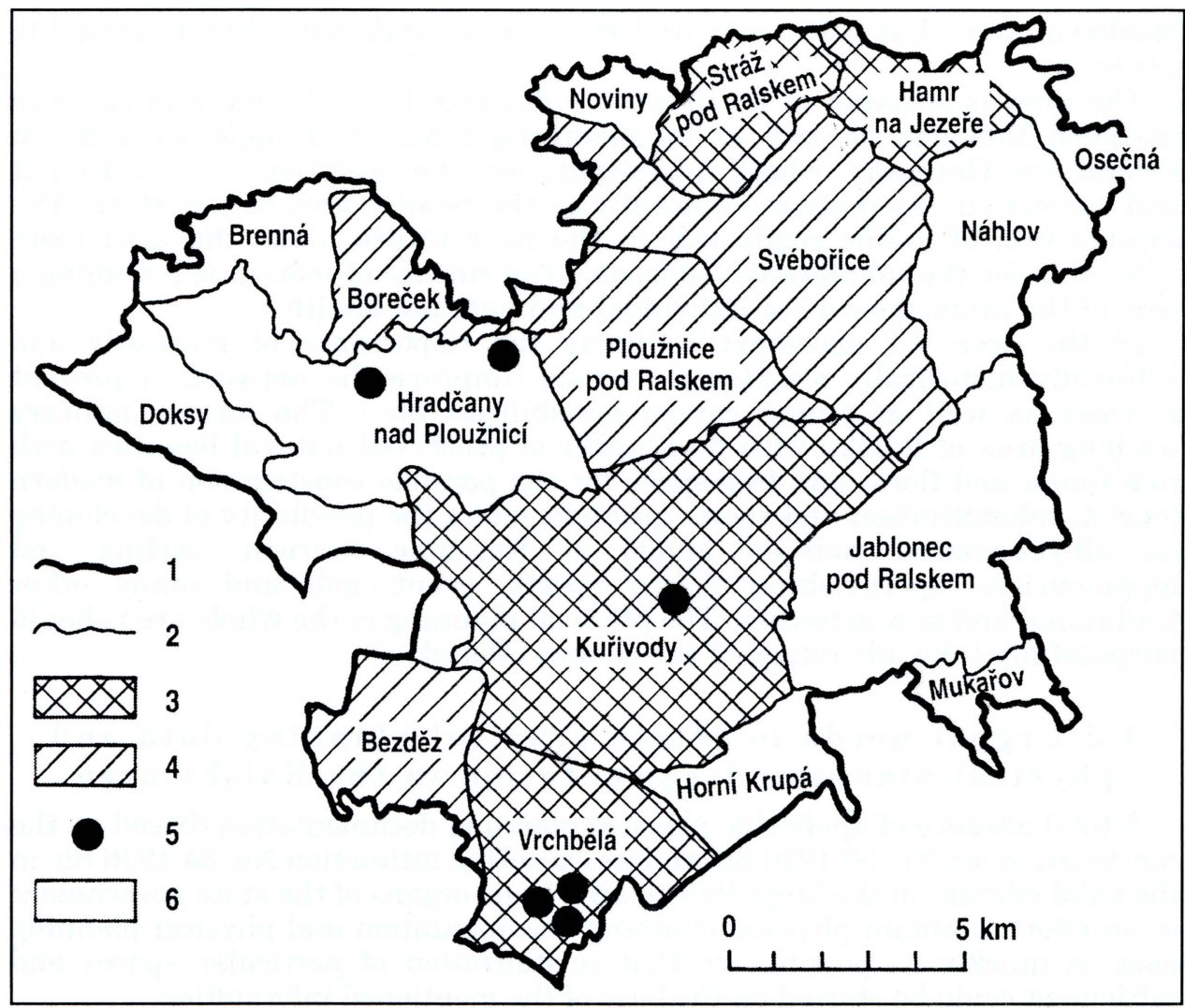

Fig. 1 - Preview of compiled physical planning data and physical planning documentation about the former military training area at Ralsko. 1 - border of the former military training area at Ralsko; 2 - border of catastral units; 3 - area plan; 4 - urban study of the settlement, 5 - urban study of the zone; 6 - area not dealt with.

adaptations and general reconstructions, at the present time the dominating problem consists in the destruction of worn-out objects and ruins.

It seems that physical planning in this area is nowadays sometimes even a cumbersome tool for the actual saving of short-termed durability residual funds, and was called on too late to participate in solving the increasing collapse in using these expiring values. Nevertheless in the structure of what remains there will be profitable and noted deposits in the terrain and park modifications and traffic roads and also the demolitions should be treated with the necessary physical-planning and building discretion.

In the physical planning of the area in question, it's necessary to call attention to the large and economically hopeful sphere of traffic business. The traffic business could be one of the activities that would significantly contribute to the economic and social revival of the whole region. The Ralsko territory lies in the immediate neighborhood of traditional recreation and spa centers (Doksy with the Máchovo jezero Lake, Stráž pod Ralskem Hamr na Jezeře, Lázně Kundratice Spa). At a short distance of $30-50 \mathrm{~km}$ lie Lužické and Jizerské hory mountains with winter-sport centers. On the other hand, summer recreation activities use the water surface esp. 
Máchovo jezero Lake, Horecký and Hamerský ponds with direct contact to the area.

The area is situated in an accessible distance from Prague and cities in northern Bohemia as well as neighbouring towns and agglomerations in Poland and Germany, whose inhabitants look for traditionally new tourist and recreation destinations especially in the nearby area of our state. The construction of traffic roads will in the near future make the area more accessible for the inhabitants (tourists). The culture of motion is becoming a part of the intensive care of individual and national health.

In the area it's necessary to apply the importance of naturally and culturally historically orientated tourism (improve the network of present services as well as tramp camps possibilities etc.). The former military training area of Ralsko with its number of preserved natural beauties with rich fauna and flora, and free space for the possible construction of modern tourist, rehabilitation and sports grounds, offers the possibility of developing an all-year-round tourism aimed at free-time tourism, cycling and hippotourism, sport-fishing, riding sports, event. golf and many other traditional and new activities. The physical planning of the whole area should purposefully take advantage of the chance offered.

\subsection{Urgent needs to obtain physical planning data and} physical planning documentation in the Ralsko area

A total absence of applicable physical planning documentation (based on the construction act No. 50/1976 Sb. and its executing intimation No. 84/1976 Sb. in the valid edition) in the large Ralsko area leads organs of the state government in an effort to obtain physical planning documentation and physical planning data as quickly as possible, so that revitalization of particular spaces and settlement could be started on the base of the mentioned information.

The district council Česká Lípa, as the obtainer, contributed in cooperation with the neighboring district councils (Liberec and Mladá Boleslav) in the years 1996-97 to acquiring the lower degrees of physical planning documentation for particular settlements in the former military zone area. These documentations and data are an important source of information and decision-making for local self-government.

Territory plans and urban studies after being discussed and passed have become a very important foundation for controlling the construction and decision-making of local self-government e.g. in regulating the localization of particular investments coming to the area.

\section{Physical plan of the large area unit Ralsko}

The foregoing existing physical planning documentation - area plan the former military training area of Mimon was formerly submitted to military use, so it's not (apart from the valuable analysis part) applicable to newly arisen social conditions.

Physical plan of the large area unit (PP LAU) Českolipsko from 1981 accepted the existence of the military area of Ralsko and didn't discuss its problems further.

In 1991 the obtaining of PP LAU Ralsko was proceeded with. The executor was Studio Botič (W. Hána). PP LAU Ralsko was certified by the Government 


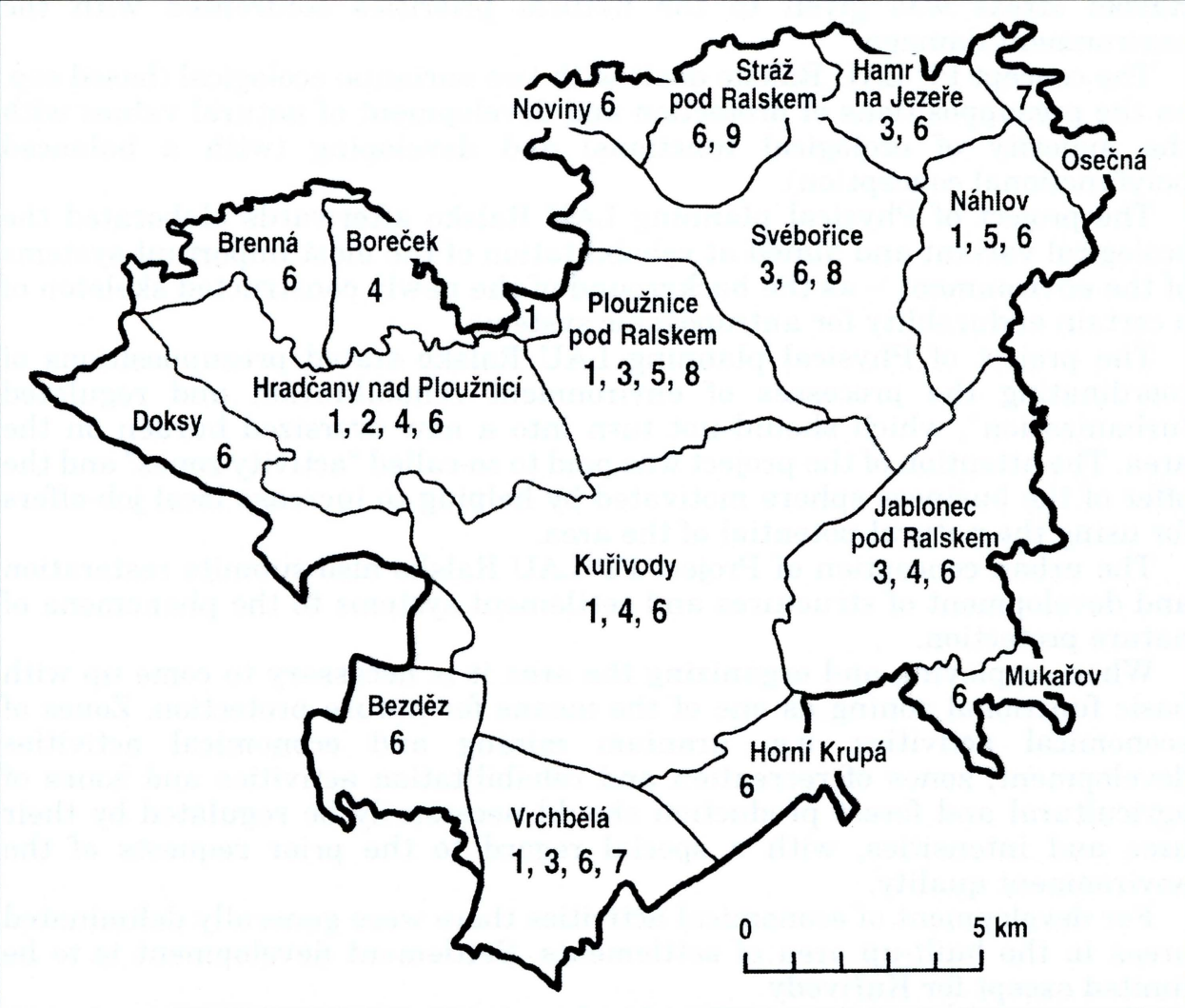

Fig. 2 - Suggested reuse function of individual parts of the former military training area at Ralsko (prevailing function) 1 - permanent residence; 2 - civil amenities; 3 - recreation and sport; 4 - production and stores; 5 - agriculture; 6 - landscape revitalisation; 7 - spas; 8 special interest use; 9 - longterm interests, gradual ending of uranium mining, airport.

decree from 19. 12. 1994 - through this its obligatory part was declared. One of its components consisted in valorization of efforts on the environment according to the law nu. 244/1992 Sb. including specification of the ecological structure of the development conception. The final version LAU was based on the priority of ecological use of the area.

The aim of PP LAU Ralsko consisted in verifying the extent of the area in questions damage, reasons and ways of restoration and regeneration and area development, which localities were and would be blocked, what limits of environment and "civilization values" in positive and negative meaning are to be respected in constructing the new urban structure of Ralsko. The aim of PP LAU Ralsko was to eliminate and solve negative displays and disproportions in the area, deliminate ways of employing the positive values and offered potential of the area, what interactions of LAU Ralsko with the surrounding area can be expected, how to join the area LAU in the context of extensive connections.

The results of research and analysis (executed on the physical planning design in the scale 1:25,000) pointed to the burden on the area of human activities and problem areas were deliminated. In the ecological part PP LAU 
Ralsko stress was given to the natural priorities confronted with the environment damage.

The concept PP LAU Ralsko dealt with two variants: ecological (based esp. on the presuppositions of protection and development of natural values with the majority of ecological functions) and developing (with a balanced polyfunctional conception).

The project of Physical planning LAU Ralsko afterwards elaborated the ecological variant and aimed at rehabilitation of the most important systems of the environment - as the background of the newly constructed skeleton of a certain endurablity for antropogenic systems.

The project of Physical planning LAU Ralsko stated presuppositions of coordinating the processes of environment rehabilitation and regulated "urbanization", which should not turn into a new oversized burden on the area. The attention of the project was paid to so-called "activity zones" and the offer of the business sphere motivated by helping to increase local job-offers for using the natural potential of the area.

The urban conception of Project PP LAU Ralsko also submits restoration and development of structures and settlement systems to the phenomena of nature protection.

When employing and organizing the area it is necessary to come up with basic functional zoning as one of the means for nature protection. Zones of economical activities, e.g. uranium mining and economical activities development, zones of recreation and rehabilitation activities and zones of agricultural and forest production should necessarily be regulated by their uses and intensities, with a special regard to the prior requests of the environment quality.

For development of economical activities there were generally deliminated areas in the built-up area of settlements. Settlement development is to be limited except for Kuřivody.

The aim of Project PP LAU Ralsko was to direct elaboration of the former military training area of Ralsko area use limits, state principles of technical infrastructure development, conditions for removing the negative effects on the environment, elaborating the regulatives of functional and space area arrangement, project the sources and reserves for maximally effective urban area development.

Apart from its basic physical planning function the PP LAU Ralsko should have become one starting data for the preparation and compiling of privatization projects.

In the interest of preserving the necessary functions in the area in situations of consequential risks and expressive ecological burden the PP LAU put stress on the necessity of undertaking cleaning and decontaminating the area as the first-rate aim of solving correspondent standards for civil use of the area.

The desirable areas to develop among others these economical spheres and activities are development of the business sphere in activity zones, development of forest economy and subsequent woodwork production, development of functions connected with healthcare, development of tourism and recreation, development of agriculture.

As the basic wayout of the area development The Project of PP LAU put stress on the need to speed up the creation of conditions for starting the privatization process. From a conclusion of PP LAU Ralsko resulted requests to apply principles of solving PP LAU Ralsko and by him brought out limits 
for physical planning preparation on the level of settlements and privatization units.

\section{Studies of the regional temper}

\subsection{A strategic development study of Ralsko}

In 1996 the Prague Faculty of Architecture, ČVUT, together with a division of Regionalists and public government of University of Economy-students, who so far hadn't dealt with the physical planning outside the scope of the standard contents of relevant subject lessons, would work out the mentioned "strategic development study of Ralsko".

In this school work they presented a number of model variants of possible development of the Ralsko area: variant "NATO", demonstrating the areas return to military use (variant of one investor) - variant "natural development "; variant "alternative"; variant "according to the councils wish"; variant "passive".

The variant "natural development" arose from the fact that Ralsko municipality is an artificially built settlement, which can more naturally be divided into a few smaller areas. These particular smaller areas would be connected to the surroundings outside Ralsko and afford new areas for an extension to this surroundings.

The "alternative" variant offered quite an uninhabited space to the voluntary groups of inhabitants with alternative ways of life, which are hardly applicable in present major society. The variant mirrors the attitude of the present young generation to marginal or even incoventional social groups in society and looking for a solution. It is a variant of "many smallamount investors" who will carry the burden of problems and probably costs connected with the solution.

The variant "according to the councils wish" mirrored the students feelings, which arose after official consultations at district councils with the idea of planned development and restoration of settlement function in harmony with the regional physical planning, restoring present huge capacities of technical networks, with expensive reconstructions of blocks of flats, with the idea of stimulating economic development to create a new attractive offer for a flow of new labor power and inhabitants to the area. The idea counted on using the investments for recultivation of the environment together with creating suitable conditions for recreation, conditions for breeding of endangered animals etc.

The "passive" variant was searched "extra". It consisted in the free affecting of external factors without purposefully deciding and influencing the unprompted conception of the solved area from the state side.

The study states, it's a very complicated area, which therefore demands a circumspect attitude to solving principle problems. The presented variants indicated the difference of possible methods of area development, considered local, political and ecological interests. It's possible, that development in reality will be the synthesis of mentioned variants at the same time. It can also be supposed, that some planned solutions also have a very real chance to be realized, esp. in using the southern part of area for all-year-round purposes and in preserving the part as a nature reservation. The conclusion of the study states that changes in the area will be put forward slowly and will 
demand a very sensitive attitude. The area isn't ready yet for fundamental goahead changes in operating (although some experts don't completely agree with this conclusion).

\subsection{Possibilities of using the Ralsko area for tourism needs}

Researching the presuppositions of the Ralsko area for tourism, indicating possible ways to create suitable presuppositions of tourism development in the mentioned area was dealt with in 1997 in the study "Posibilities of using the Ralsko area for tourism needs", edited by mag Consulting Co. Ltd. Prague in February 1997.

In this study the Ralsko area is characterized from the point of view of possible employment in the sector of tourism as quite unprepared, being one of the least inhabited areas in the ČR. The study considers the problems of Ralsko in the question of "depopulation" and its present partial depreciation by military activities (earth and water contamination, insufficient level of infrastructure). These negatives still reduce the areas attractivity for potential investors.

The area will - from the point of view of permanent, long-termed landscape values -be very suitable esp. for sport and recreation activities - walking, cycletourism, agrotourism and riding sports, fishing and hunting, water recreation and other sport activities such as golf, tennis, athletics etc.

A significant aspect of possible developments could be health rehabilitation - a spa. Actually it'll be various forms of ecotourism, resp. countrytourism with a need for nature protection development in this area.

The study considers the importance of tourism in this area as one of the ways to integrate the area into tourism branches with the neighboring area and being connected even from the economical function point of view. From these views we find it natural to include the part of naturally declivity area of Ralsko in relation to general centers such as Doksy and surroundings, Stráž pod Ralskem - Hamr na Jezeře, Bělá pod Bezdězem, and Lázně Kundratice Spa. In these centers the bases of tourism infrastructure have already been built, centers can also be suitable wayouts of not only tourist signed tracks and cycletracks but even offer the first services for successive development of Ralsko area tourism, to be the first support to participants of tourism and later a natural competition of growing interest in offering services in other centers ( settlements) in the area of Ralsko.

It is not realistic to hope to secure development of this area without the financial support of the state, esp. for creating the basic infrastructure - there it would be necessary to direct essential state donations. Constructions of sufficient background for tourism activities will further be dependent on the interest of domestic and foreign investors in the area, which could be attractive even for international tourism.

\section{Physical plannings of settlements and urban studies of settlements}

Before 1996 these plans were worked out: physical plans of settlements (PPS) Osečná a Lázně Kundratice, PPS Doksy.

In the years 1996 - 1998 the following physical planning documentation and physical planning data were worked out: PPS Bělá pod Bezdězem, PPS 


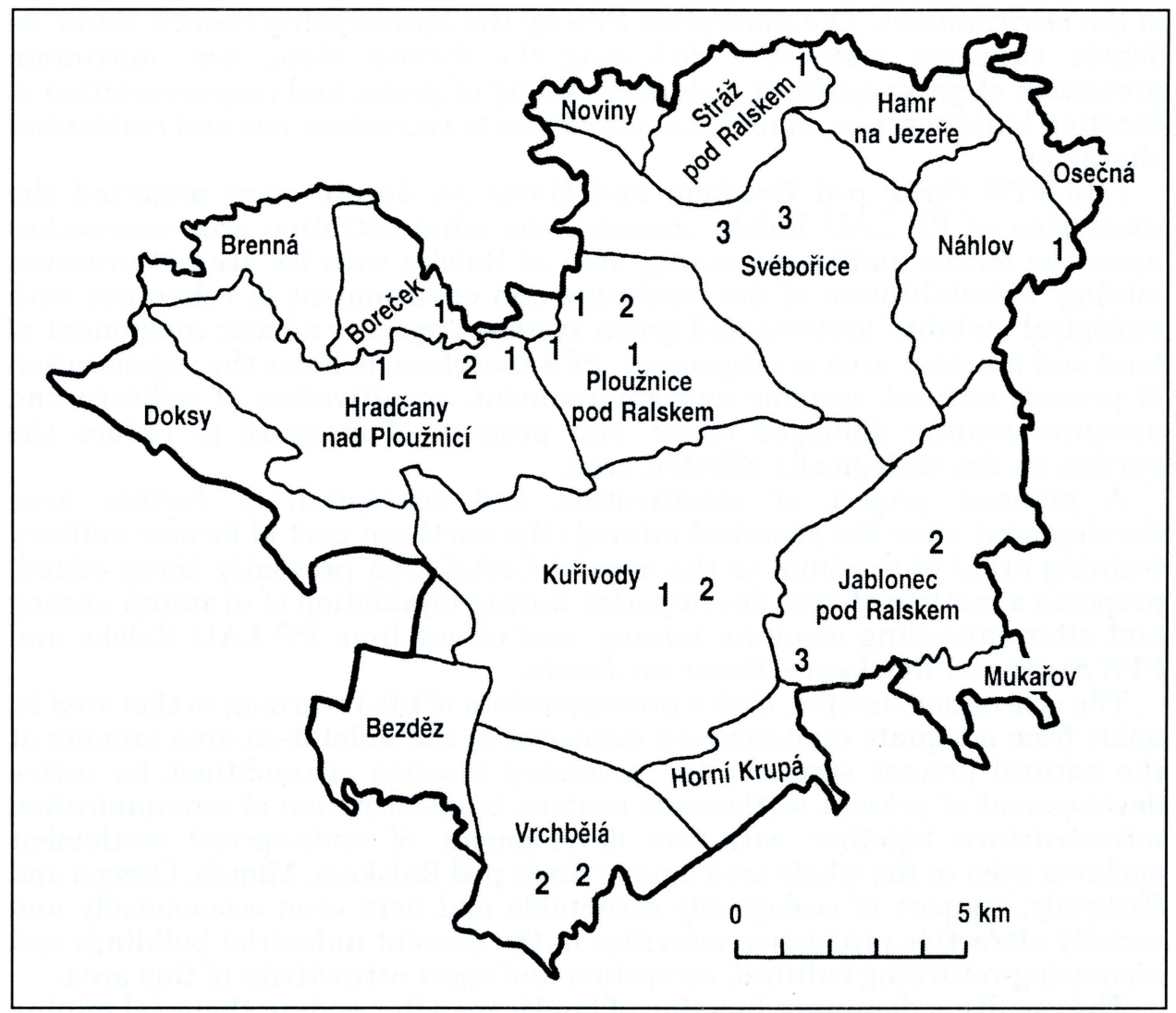

Fig. 3 - Urbanisation areas. 1 - Preseved settlements, modernisation funds; 2 considerable renewal of original settlement; 3 - unrenewed settlements with different aims.

Stráž pod Ralskem and Hamr na Jezeře, PPS Kuřivody, Urban study Jablonec (Jabloneček), Urban study Boreček, Urban study Ploužnice, Urban study Hvězdov I - II, Urban study Svébořice I - II, Urban study Náhlov, Urban study of Bezděz municipality.

\subsection{Physical plans of settlements}

Stráž pod Ralskem and Hamr na Jezeře

The project PPS arises from the suppression and successive liquidation of the uranium mining industry, which had a dominant importance here in the last 30 years, significantly suppressed former recreation functions and also very negatively influenced other following settlement functions and disturbed, together with military activity in the neighboring area, the former balance of the environment.

The project PPS of function area use in the area of Stráž pod Ralskem preserves the main living and producing functions of the settlement with neccessary reductions of area after the foregoing mining. It aims to restore and develop recreation functions, which are mirrored in the settlement character, and it also aims to create suitable conditions for the rehabilitation 
of the environment. The conception PPS by the Municipality council Hamr na Jezere supposes restoration following the former state, esp. maximum protection of grass surfaces including adding of grass, and reappreaciation of function buildings use, aimed at their return to recreation use and residential character.

Into PPS Stráž pod Ralskem and Hamr na Jezeře were projected the conclusion of PP LAU Ralsko ,because the administrative area encroaches upon the former military training area of Ralsko with its area of uranium mining. Rehabilitation of the landscape and environment in coherence with ecological stability systems and green system project is a basic component of land and function area arrangement. PPS therefore includes the regeneration of present natural systems and environment, recultivation of military and uranium mining damaged areas, and projects of measure to reduce the burden on the ecologically affected area.

A planned project of recultivation and conception of further area development after the chemical mining (the northern part of former military training area) of uranium in the area of Ceská Lípa presently being edited, proposes a method of area development during liquidation of uranium mining and after cancelling uranium mining, and comes from PP LAU Ralsko and PPS Stráž pod Ralskem - Hamr na Jezeře.

The conception accepts, that a presupposition of life returning to this area is, apart from adequate revitalization measures in the unbuilt-on area (aiming at the natural process support), the necessary creation of conditions for active development of present settlements centers, transformation of communication infrastructure together with the development of wide-spread settlement enclaves even in the whole area among Stráž pod Ralskem, Mimoň, Osečná and Kuřivody, support of ecologically acceptable and here even economically and socially attractive production activities in the present industrial buildings and increasing-returning cultural, recreation and sport attractivity of this area.

The resulting dominant function of landscape after ending chemical mining will also consist in "soft" forms of recreation including touring, cycletouring, water sports, horseriding, agrotouring.

\subsection{Jablonec (Jabloneček) Building Study}

A former country settlement, at present abandoned (without pernament inhabitants). On an upper land table situated southwards from the settlement there lies a giant building (former rocket store with a number of spacious garages). Most of the formerly used military buildings apart from the former rocket stores are in very bad condition, suitable for demolition. The settlements surroundings are mine-contaminated.

Development is based on complete area analysis, which states the limits of utilization of the former settlement locality in the context of its extensive area. At the same time there conditions were stated for further use of the former rocket store esp. regarding traffic service of the zone. The district council has through the Jabloneček building study worked out a finished view of a possible way to use this complicated area.

The significance of landscape is in Jabloneček given priority in considerations about possible use. The value of Židlov shooting-range space consists in a rare structure of botanic layer - the highest economical value in the area usable in a development program. This is the reason, why it is not recommended to forestate the space of Židlov shooting-range. 
4.3 Building studies of the settlements Boreček, Ploužnice pod Ralskem, Náhlov

The settlements Boreček, Ploužnice and Náhlov, situated on the very edge of former military training area of Ralsko, are small settlements with populations of up to 200 inhabitants, which survived in the military training area of Ralsko. The worked-out building project preserves them and brings them back to life.

Boreček, situated by the road II/270 Mimoň - Doksy is divided into two parts (living by the road and production by a service road near the airport at Hradčany). In the production part there is SAP Facility - veterinary and extermination works permanently run with an above-regional activity. The area of facility, where they work on further raw materials esp. dead animals and fish, has a proclaimed zone of hygiene protection (PHO). All buildings (inhabited included) situated in PHO will be successively replaced. The facility SAP is proposed to be preserved in the study, including other impure kinds of production (area ELO). Further development is limited by agricultural estate fund protection.

Ploužnice pod Ralskem lies directly by the road II/268 Mimoň - Mnichovo Hradiště. The settlement is formed in two parts connected together by an upset structure of buildings on both sides of the Ploužnický stream. It is planned to preserve the present traffic network and the structure of settlement building with all-buildings use.

Free areas along the road in the direction of Hradčany - Hvězdov II, suitable for construction of family houses, could be used for this purpose. Free areas by the road II/268 are recommended for use.

Náhlov, agricultural settlement, where the agricultural character will remain in the future. Restoration of agricultural activities in cadastral and its own large area in Náhlov will start. Stabilization of the present population and partial population-adding will be connected to the development of agricultural production. Population stabilization will be necessarily supported by the restoration of basic civil and and technical facilities - to create the possibility of a rise in further business activities offering employment. Support should also be given to recreation, both individual (utilization of abandoned family houses as cottages) and collective (reconstruction of a former school as hostel accommodation), in a more extensive context (cycletouring, touring).

\subsection{Building studies of settlements Hvězdov I - II. and Svébor̆ice}

\subsubsection{Hvězdov}

In the training center an extensive barracks complex, soldier shootingrange and training gound for chemical troops were constructed. The area was divided into three parts: Hvězdov I, situated northwards from the chain of Hvězdovské ponds, Hvězdov II, situated southwards from this very attractive pond chains , and Hvězdov III, situated in the southeastern direction.

The localities Hvězdov I - II. and near Svébořice lie in a permanently attractive environment with a chain of ponds. Studies here presented a project of locating low-floor flat buildings with recreation facilities and background for participants in certain sports: golf, tennis, cyclecenter, horseriding, fishing. The study makes use of the Svébořices background as a refuge for endangered animals. Of civilization elements, the building study makes use of the basic communication network of the area, preserved usable family houses and a 
school area. All present, mostly mounted wood buildings (Tesko), from which a whole row is in an unacceptable condition, are planned to be liquidated.

In the locality Hvězdov I - it is possible to use esp. areas, which are former military carparks situated northwards from the thoroughfare. These areas are suitable for construction of family houses and recreation background.

In Hvězdov II the construction of recreation buildings in areas of former military accommodation has been projected. Sport activities will be used e.g. a present football pitch. Northwards from the building Ministry of Defence ČR situated in the former military accommodation complex is a building study projected for use not only for recreation purposes, but even as a possible store, or ecologically suitable industrial production. Buildings in the locality of the former military shooting-range are recommended to be liquidated by the building study and the area should then be razed and returned to naturerelated ways of use without any construction.

In the locality Hvězdov III there are buildings and areas which are still used by the army - special stores for chemical troops.

\subsubsection{Svébořice}

The locality is connected by road in a western direction to Mimoň: The building axis of area is the main thoroughfare Stohánek - Hvězdov Ploužnice in an east-west direction.

In Svéborice, a settlement, that was completely destroyed, utilization of the area is limited by facilities for uranium mining, esp. by monitoring bores and hydrobarriers. In the locality of Svébořice I - Nový Dvưr a presently unfit for use barracks complex with a carpark and store space was built. In Svébořice there was an area of tanks shooting-range. Fragments of shooting-range equipment have been preserved from the area (observation points, garages, first aid accommodation). The devastation of the area had increased so much, that the study proposed the demolition of most of the present buildings and razing other areas completely.

Liberec Zoo has shown interests in parts of Svéborice with a project of costructing a breeding station of the worlds most endangered species of animals. At present the project is being cosidered by the Pilot Study NATO CCMS. It should be situated in the area of the former military shooting-range (Svébořice II) with a range of approx. 200 ha including the space for a fowl-run and relevant technical and service background. Here there are only acceptableon-certain-conditions abandoned garages and observation points. For staff accommodation, laboratories, special education facility, research workers accommodation and expert public the above-mentioned project counts on using a locality in Nový Dvür. The state of appartment houses is already very bad now, and previous ideas on their utilization for living are unacceptable.

In the area dealt with it will be necessary to raze areas, situated southwards from the Stohánek - Mimoň road. Some of these areas can be used for the construction of recreation accommodation facilities with sports facilities (e.g. tennis courts).

To develop all the activities in the mentioned area it will be necessary to build quite a new technical infrastructure and carry out a reconstruction of roads.

\subsection{Physical plan of Kuřivody settlement}

Kurrivody is the settlement of former military training area of Ralsko where the most expansive development is expected. Kuřivody is reasonably situated 
transport-wise on the crossroads of a II.class road (Mnichovo Hradiště Mimoň - Nový Bor ) with a road Bělá pod Bezdězem - Osečná, on which traffic importance will grow considerably. Kuřivody was already, before the rise of military training area of Ralsko, the most important settlement in Ralsko. Further development of Kurrivody is enabled by considerable reserves in the settlements built-up area and some structurally well-fit-for-use areas of industry and half-abandoned complex of blocks of flats. The settlement has given shelter to families moved from the area affected by the results of the disaster at Chernobyl powerplant - Volhynian Czechs.

The living function with the necessary civil facilities and services, production and business activity (for these purposes esp. abandoned and hardly used and also already built-up buildings) and number of services for accommodation, tourism facilities and some others (recreation, wood, agricultural) activities will be relevant for settlement.

Development of the living area will according to the worked-out studies of the central zone and PPS be realized southwards from the road II/268 in the area between the school, church and townhall on the eastern side and gothicrenaissance Waldstein fortress, which will be restored as an interesting dominant of settlement on the western side.

\subsection{Building studies of the settlement Hradčany nad Ploučnicí - present living zones}

Hradčany, which also survived in military training area of Ralsko lies on the II. class road Mimon - Doksy in close promixity to the most preserved natural part of the former military training area - the Hradčanské walls, chain of Hradčanské ponds and meandres of the Ploučnice River. The area is a component of the prepared National Natural Reserve Doksy Sandstones and Wetlands. They are situated in immediate contact with the runways of the former military airport.

The building study preserves the function of permanent living with mild development and recreation with pond use for bathing, restaurants etc. Hradčany could become a starting point for tour-tracks. Through building the system of cycletracks and walktracks Doksy - Hradčany - Ploužnice Svébořice and Stráž pod Ralskem - Hamr na Jezeře would be connected. How the airport is used will indicate the development rate of the settlement.

\subsection{Building study of the living zone at $\mathrm{Hradčany}$ airport}

The airport area was divided into three zones: zone of airport service functions (northeast, northwest, south), runway area of airport itself, zone of living and civil buildings.

The zones of living, amendment and production buildings connected with the airport have potentially 965 flats in living houses, number of buildings, and areas formerly used for special purposes. They are situated in very ecologically devastated areas. The utilization rate of all facilities will be considerably limited by investors interest, depending on attractivity of running the airport and considing the rate of economic profit and the advantage of reconstruction of buildings and and ecological admission of razed areas reuse. The zone of living and civil buildings are among the most attractive in the area of the former military training area. Its situated between road II/268, Ploužnický stream and Hradčany. 
The project of the building study of the zone comes from these presuppositions:

1. The zone will form a fully-valuable self-governing living unit with a higher share of facilities and production in connection with the running of the future airport.

2. Settlement of the zone will be realized through active programs of gaining new population in Ralsko municipality in connection with real interest in occupying the reconstructed buildings.

3. A high share of facilities and production will be understood in connection and also on the basis of a government stated area protection of the neighboring airport for regional work and the real interest of business subjects in using the present buildings and areas in the zone.

4. The extent and utilization of zone function areas will be projected in harmony with the "civil character of former military functions (facilities, living, production). The already built-up areas will be proposed for use regarding the necessary investments in their sanation. However no new areas will be occupied.

5. For traffic use of the zone the present road network will be used to the maximum. Fit-for-use facilities of technical infrastructure will form a skeleton component for supply with a necessary media system.

6. All wood mounted buildings Tesco and blocks of flats of a russian type (Kijev) will be razed, and eventually reconstructed. The degree of building intervention in other buildings will be projected according to the already acknowledged purposes, res. according to the needs of building conception.

7. The space structure of the zone comes from a demand to form a quite fully - valuable living facilities and quality airport background, living forms will be connected as much as possible with the preserved grass cover. Business activities do not need negatively disturb the living area.

8. All activities placed in the zone (e.g.including the technical security) must not decrease the quality of restored environment.

9. A potential noise level from the regional airport $75 \mathrm{dBA}$ reaches the area, so the projected function buildings utilization must respect this.

\section{Building studies of zones}

\subsection{Building study of living zones Vrchbělá}

In the locality Vrchbělá, which is situated beyond the district border of Česká Lípa (in the district of Mladá Boleslav, by Bělá pod Bezdězem), there are for PPS delimited three little localities for the construction of family houses (one for above-standard living ) in an attractive environment of the upper flow of the Běla Brook with a ponds chain. The owner of two already edited building and architect studies on the utilization of hillsides on which the sun shines, on the right bank of the Bělá Brook, is the town council of Bélá pod Bezdězem. The studies were edited in 1996 by SAUL Co. Ltd. Liberec. The studies make use of the position of suitable localities with a natural bathing pool in the valley of the Bělá Brook and present employment possibilities and services in Bělá pod Bezdězem, and offer very attractive kinds of buildings for living and even partial utilization of an older house-restoration and modernization fund for the needs of hire and family living.

The localities are situated in the natural frame of a pine wood in a corrugated terrain and their advantage is e.g. the possibility to use the extraordinary local quality drinking water sources. Attractive aspects of the place are gorgeous 
wood coulisses, grown-up dispersed green in immediate contact with areas for living and peaceful giant and immediate massive wood background. The studies owners believe, that living there will become a very attractive offer to the population of Mladá Boleslav (with extraordinary lucrative employment possibilities and on the other hand a scarcity of attractive living localities in family houses in the city, nearly crowded with blocks of flats and traffic). The projected living localities in Vrchbělá could also make use of future job-offers in services in the neighboring zone for tourism, sports and spa.

\subsection{Building study of a recreation, sport and healthcare zone, Vrchbělá}

A locality for recreation and tourism, spa (rehabilitation) and sport activities is very suitably situated in the north end of Bělá pod Bezdězem in a mild corrugated terain between mostly pine growths of wood character. The zone is separated from living localities by the pine wood and has a direct connection on the opposite side (southwestern) to a state road in the section Bělá pod Bezdězem and Doksy. The study of this zone counts on making use of business interest in services of domestic and foreign tourism for constructing capacity accommodation facilities (camps, caravan camps and motels) in the locality of this zone and even for the need of lightening the recently unbearably overcrowded area of Máchovo jezero Lake in connection with the offer of local recreation sports developing possibilities in the until now undisturbed landscape northwards from Bělá pod Bezdězem. The study offers the establishment of a sport center in a partial area of the former tank shooting-range aimed at riding sports and agrotourism, tennis, athletics and various ball sports, offering possibilities of making use of the landscape for cycletouring and touring at the same time in connection with the projected spa zone utilization.

Utilization of the former military area part even for healthcare was a substantiated demand of the owner on the basis of the project PPS by the town of Bělá pod Bezdězem. Motivation has come about here from a peaceful area location in the middle of woods on dry and warm sand soils with mostly pine growths (fytoncid effects of resin), quality drinking-water from the local sources (suitable even for sucklings) and also a suitable cooperation in effective utilization of the necessary sport facilities in the sphere of tourism, which traditionally brings spa activities too.

The area of the former tank shooting-range, which is in the northwestern zone end is also connected to the outlet in the direction of a II. class road and mentioned capacity carparks, has been suggested a polyfunctional utilization, esp. for sports demanding large continuous areas (paintball, horse polo, steeple-chase), eventually for use for open-air exhibitions and social meetings etc., which can both take advantage of the easy road connections and highly attractive natural coulisse of the freed wood-steppe space with a panoramatic outlook (mountaintops of Bezděz, Ralsko, Ještěd etc., attractive esp. for tourists).

The study demonstrates the goals of pernament utilization of most preserved buildings by presenting drawn-plans with the use of documentation kept in archives of Bělá $p$. Bezdězem council. The zone conception uses the existing cubic composition of the former military area.

The limiting factor for restoration and construction of the mentioned zones in Vrchbělá is the construction of technical and traffic infrastructure. 
HÁNA, W. (1994): Územní plán velkého územního celku Ralsko. Ateliér Botič.

Strategickorozvojová studie Ralska. 5 modelových variant. Fakulta architektury ČVUT, odbor regionalistiky VŠE, Praha 1996.

Územní plán sídelního útvaru Osečná a Lázně Kundratice. SAUL Co. Ltd., Liberec.

Územní plán sídelního útvaru Bělá pod Bezdězem. Ateliér Mladá Boleslav, Okresní úr̆ad Mladá Boleslav.

Územní plán sídelního útvaru Kư̌ivody.

Územní plán sídelního útvaru Stráž pod Ralskem a Hamr na Jezeře.

Urbanistické studie: Jabloneček, Hradčany nad Ploučnicí, Boreček, Ploužnice, Hvězdov I, Hvězdov II, Svébořice, Náhlov, Bezděz. SAUL, Co. Ltd., Liberec.

Urbanistické studie: obytné zóny Vrchbělá I, Vrchbělá II; rekreační, sportovní, lázeňské zóny Vrchbělá, obytné zóny Hradčany. SAUL, Co. Ltd., Liberec.

\section{Sum mary}

\section{CONTRIBUTION OF PHYSICAL PLANNING AND REGIONAL POLITICS TO THE REVITALIZATION AND NEW USE OF THE RALSKO AREA}

The former military training area Ralsko is again being used for non-military activities. Compared to the pre-military era, however, Ralsko is a different country now reflecting all the drawbacks of the past time: it includes landscapes devastated by uranium industry, mostly disused military buildings and just a handful of original settlements.

On the other hand - since Ralsko has been virtually inaccessible for anybody except military personell until not long ago - the nature quality is relatively high. Ralsko has diverse landscapes with a number of lakes, sandstone rocks, and wooded hills dominating the country. Inquisitive visitors can find little known castles here that have been until recently completely hidden.

Forests, meadows, and fields again teem with life as gasoline leaks from military vehicles have been stopped. Also the uranium ore is not mined any more and long-distance pollution has been significantly reduced.

There have been different tasks that must have been solved in order to bring new life to Ralsko. These include water decontamination, reduction of uranium mining as well as building of new gas- and electricity network. Technical infrastructure, however, requires a lot of money: new water pipes, water treatment plants, and transportation lines will have to be built. These investments are usually allocated to the existing towns on the margin of the former military area.

Most of the technical infrastructure has already been started and all lines will soon be expanded into the heart of the miliary area. The most dangerous hazards resulting from the former military use are now removed and the area is open for tourists. Facilities, however, are minimal except basic services in a few villages on the margin of Ralsko. As soon as technical infrastructure and transportation lines are complete, some areas would become suitable for permanent housing, leisure activities, sports, and recreation. This is anticipated especially on places where former settlements did originally exist.

Physical planning documents anticipate revitalization of permanent housing and also creation of job places. Most jobs would be generated in services, spa treatment, accommodation and sport activities.

In some areas where nature quality is high new activities will be restricted for the sake of nature protection. This is the case of Dokeské pískovce (Doksy sandstone area) or Jabloneček. Also water sources enjoy a considerable degree of protection and thus will much influence the location of future settlements.

(The author is with Česká Lípa District Office, Děčínská 389, 47035 Česká Lípa.)

Arrived to the editors office on May 6, 1998

Recommended for publication by Václav Poštolka and Zbyněk Ryšlavý 